\title{
Capacity Building of Afghan Universities in Geology and Minerals Education
}

\section{Bahawodin Baha, University of Brighton}

Dr Bahawodin Baha is a principal lecturer at University of Brighton in England since 1989, where he has been teaching and conducting research in electronic engineering.

Besides his teaching in the UK, he has been helping Higher Education (HE) in Afghanistan since 2005 and has conducted my projects on improving higher education in Afghanistan. Recently, he was on sabbatical leave for two years and was technical advisor at the Ministry of Communication and Information Technology (MICT) in Afghanistan. During his work, he worked very closely with the Ministry of Higher Education (MoHE) and Kabul based universities.

He was a visiting scholar at Virginia Polytechnic, Institute and Sate University in the USA in 1991 - 1992.

\section{Dr. Hamidullah Waizy, Kabul Polytechnic University}

Hamidullah Waizy is an assistant professor at the Department of Geological Engineering and Exploration of Mines, Kabul Polytechnic University, Afghanistan. He has received his first BSc (Hons, 2008) degree in Geology from the aforementioned Department. He completed his second BSc (Hons, upper 2nd class), MSc and PhD in Geology at University of Brighton in the UK. His PhD studies were about the Geology and genesis of the Aynak Copper Deposits in the Kabul Basin, Afghanistan which he has completed in 2018. In addition, Hamidullah Waizy was employed as demonstrator and lecturer on the casual basis at University of Brighton while he was conducting his research and he was teaching courses such as mineralogy, petrography and economic geology. 


\title{
Capacity building of the Afghan universities in geology and minerals education
}

\begin{abstract}
Capacity building of engineering institutions, particularly in subject disciplines related to geology and natural resources is a major challenge for the present government in Afghanistan to tackle. It is crucial to prioritize and plan the growth of higher education specifically in engineering, and technology, which will have positive impact on the standard of living in Afghanistan.

The aim of this paper is to briefly review the progress of educational development in geology and minerals in Afghanistan during the last two decades. The main challenges of curriculum development and capacity-building of the Afghan universities will be highlighted. Practical recommendations will be made to address these challenges which can improve the quality of such education in the country and subsequently can lead the Afghan people towards a better, more selfsufficient future.
\end{abstract}

\section{Introduction}

Afghanistan has some of the most complex and diverse geology in the world. The oldest rocks are of Archean age, which are succeeded by rocks from the Proterozoic and every Phanerozoic system up to the present day. The country also has a long and complicated tectonic history, partly related to its position at the western end of the Himalayas [1].

The above diverse geological foundation has resulted in significant mineral resources with over 1,400 mineral deposits and occurrences recorded to date [1]. Historical mining focussed mostly on precious stone production, with some of the oldest known mines in the world established in Afghanistan to produce lapis lazuli for the Egyptian Pharaohs [1].

Recent exploration by Russian and Afghan geologists in the 1960s and 1970s resulted in the discovery of significant resources of metallic minerals including iron, copper, cobalt, zinc, lead, chromium, gold, silver, lithium, uranium, rare earth elements together with non-metallic minerals including halite, talc, marble, sulphur, bauxite, mica, oil, gas and coal, and precious and semiprecious stones including emerald, ruby, lapis lazuli, garnet and spodumene. These mineral and natural energy resources were re-affirmed by most recent studies and estimated to be worth more than three trillion US Dollars [2, 3]. The issue of the rich mineral-resource base in Afghanistan in recent years has become a point of vigorous discussion and debate amongst geologists and political 
circles. Following decades of war and instabilities and the establishment of the new government with the assistance from the international community in 2001, the natural resource story of Afghanistan has been paramount. World-class ore deposits of copper, iron, and rare earth elements, a sufficiency of oil, gas, coal, precious stones, and a number of other industrial minerals have drawn the world's attention.

The objectives of this paper is to investigate historical background including the recent limited progress of the subjects related to geology in Afghanistan and identify the main challenges to improve such education. Hence, recommendations have been made to further enhance the quality of such education which, from the author's point of view, is vital for the country.

\section{History of geological education in Afghanistan}

The history of geological studies in Afghanistan comprises three phases. The first covering many centuries is characterised by the development of ancient mining; the second phase lasted from the 1880s to mid-1950s when a number of geologists started traversing Afghanistan, at first recording the geology along the main caravan routes and then later along the arterial motor roads. The third phase started in 1955 when the Afghan government inaugurated the directorate of National Geological Survey [4].

The Afghanistan Geological Survey (AGS), under the Ministry of Mines and Petroleum, is the national custodian of geoscientific information. The AGS started the first purely mapping operations, followed by exploration and evaluation of the mineral resources of some of the more promising localities. Much of this work was achieved with technical assistance and cooperation from countries such as Germany, Italy, France, and the former USSR (Union of Soviet Socialist Republics).

The legacy of Afghanistan-Soviet co-operation is extensive and with the help of Soviet geologists, the systematic mapping of the whole country was undertaken at 1:500,000 scale and extensive mineral prospecting was initiated. The present AGS building was originally constructed and equipped by the Soviets, though it was subsequently wrecked during the three decades of civil war. Afghanistan was progressing well during 1970s when the unfortunate instability started with a military coup and subsequent wars which affected every sector including higher education; most educational institutions were severely damaged and some were totally destroyed.

Following the fall of the Taliban regime, the Afghan Government with the assistance from the World Bank, began to formulate a mining sector strategy and policy. Soon it was recognised that 
there was a need to rehabilitate and reconstruct the AGS building in order to perform as a modern geological survey and implement a program of geological mapping and resource assessment using modern concepts and methods. In response to this need, the British Geological Survey (BGS) and United States Geological Survey (USGS) started to assist the Afghan government and resumed collaborative projects with the AGS and Ministry of Mines and Petroleum in 2004. The AGS could be regarded as entering a fourth phase. The wrecked buildings have recently (2006) been renovated and refurbished by USAID. Since 2004, the BGS and US Geological Survey have developed extensive programmes of retraining and process reform [1].

To establish a proper mining industry in the country, it is essential to train the required workforce and therefore, the previous Afghan governments established geology and mining related education at Kabul University, and then at Kabul Polytechnic Institute which was established in 1970 as part of the technical assistance from the USSR.

The main objective of the geology education at Kabul University was to train geology teachers for various high schools in the country, however, the objectives of geology education at Kabul Polytechnic institute was to train suitably qualified engineers in the following areas:

- Geological engineering and mines exploration

- Exploration for oil and gas

- Underground mining exploration

To train engineers for the above areas, the faculty of Geology and Mines was established in 1979 at Kabul Polytechnic University and has been playing a major role training engineering at undergraduate, postgraduate and graduate levels. The contribution of graduates of this faculty in construction and rehabilitation of the country is considered as valuable as others. There are five graduate departments and one general department in the faculty, summarized as follows [5]:

- Department of Geological Engineering and Exploration of Mines - established in 1967

- Department of Oil and Gas Mines Engineering - established in 1967

- Department of Open Pit Mining Engineering - established in 2012

- Department of Underground Mining Engineering - established in 1970

- Department of Engineering Geology and Hydrogeology - established in 2013

- Department of Physical Training, established in 1967. 
Since the establishment of this Faculty more than 3000 engineers have been graduated in specialized subjects. These engineers have had a valuable and important role in exploration of mineral deposits, mining, industrial affairs, development and improvement of national economics of Afghanistan.

\section{The progress of higher education in the last two decades}

Higher education sector in Afghanistan has experienced substantial progress in terms of student numbers entering the universities, in addition to establishing new colleges and universities in the country. According to the Ministry of Higher Education (MoHE) strategic plan 2014-2019 [6], while there were only six public universities and no private universities or higher education institutions in Afghanistan before 2002, the number of public and private universities in 2015 rose to as many as 126 , of which 34 are public and 92 are private.

Similarly, the number of students in the same period has risen from less than twenty thousand students to nearly three hundred thousand, as shown in Figure 1.

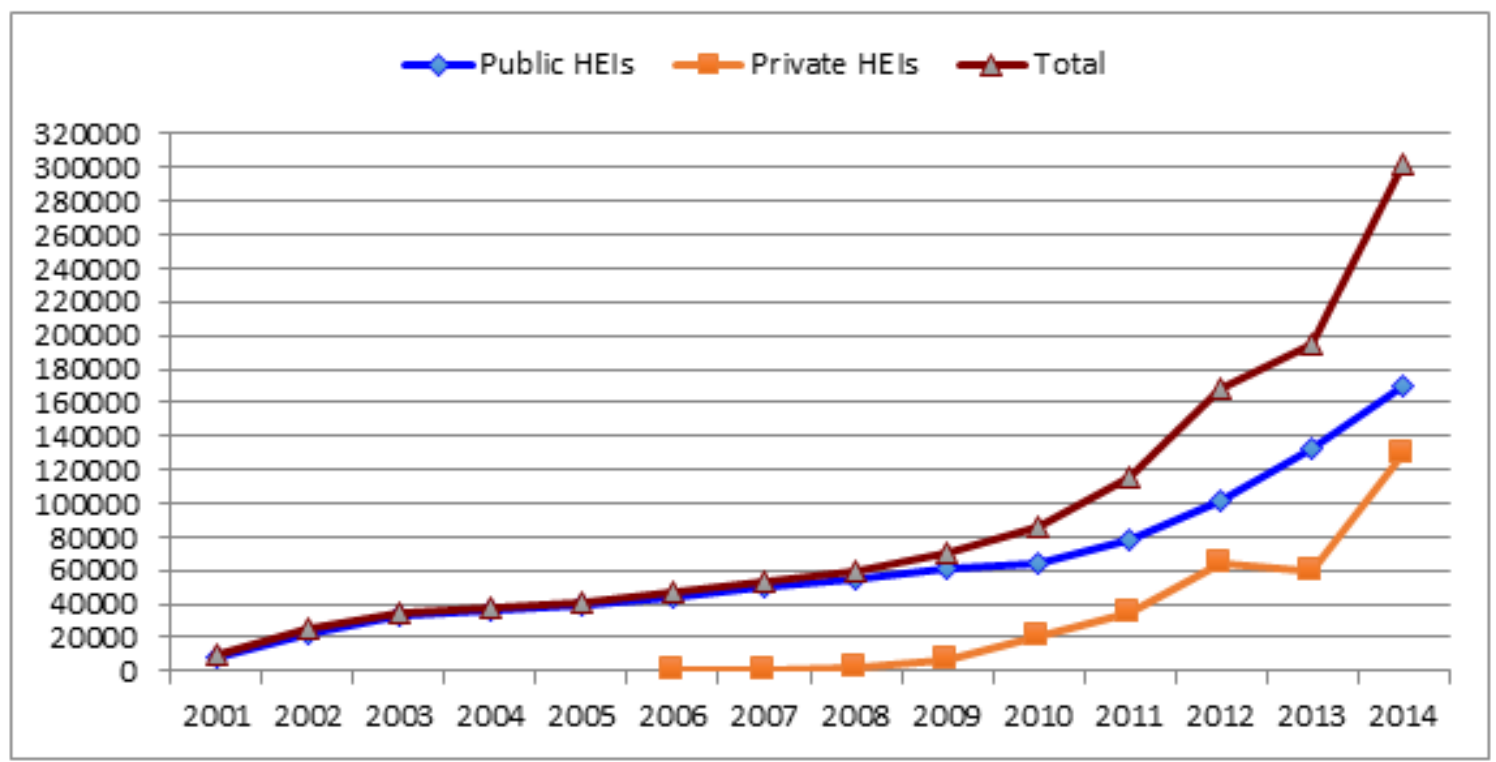

Figure 1: student numbers entering higher education, 2001 - 2014. Source: MoHE data 20012014 [7].

Furthermore, it is predicted that the number of students will increase by approximately $12 \%$ annually for the next four years. As the number of high school graduates in the country is increasing year by year, therefore, the number of students entering higher education will increase even further in the future [6]. Afghanistan has a very young population and the numbers in youth cohorts are certain to increase for the foreseeable future [6].

According to the MoHE figures, approximately $60 \%$ of students are studying science and engineering and the remaining $40 \%$ are studying social science disciplines. 
Because of poor economic conditions, the university education is free and students are admitted to public universities on the basis of university entry exam results. Therefore, admission to the universities is very competitive in the country.

As education in geology and other engineering disciplines is crucial for the economic development, therefore it will be highly productive to improve the quality of scientific and engineering education.

Despite the increase in the number of students entering higher education and the establishment of many universities and higher education institutions throughout the country, the provision and quality of higher education are still not very strong. Therefore, graduates from all subject disciplines including geology will always find it difficult to compete in the job market at regional and international level. The progress of geology- and mines-related subjects, which are primarily provided by KPU, will be discussed in the next section.

\section{The progress of geological education at the Kabul Polytechnic University (KPU)}

KPU was established with the help of the USSR, and the curricula in all subjects were designed according to the old USSR system and were taught in the Russian language. The curriculum was not updated and therefore, it was not sufficient to fulfil the requirement of the industry and job market at present. With the arrival of the international community in 2001 to assist the Afghan government with the reconstruction of the country, it was not easy for the KPU graduates to find suitable jobs related to their skills and field of interests, therefore the KPU started to renew and develop the curricula and syllabus according to the need of industries and the job market.

The faculty of Geology and Mines in KPU has a mother role for other geological faculties and departments at universities in the provinces, and all their junior lecturers and students have been working under the close supervision of their counterparts at KPU. In addition, the KPU lecturers assess and supervise practical and fieldwork activities, and final year projects of the newly established geological faculties in the provinces. Due to the major role that KPU has in the development and prosperity of the country, it was able to receive assistance and contributions from international and national organizations and institutions in the recent years. KPU has signed several memoranda of understandings (MoUs) during the last ten years, focusing on the mutual collaboration in different areas such as curricula and syllabus development, exchange programs for lecturers and students, capacity building and providing opportunities for the academic members to pursue higher qualifications such as masters and PhDs. Some examples of such MoUs with international universities/organizations are listed here: 
1- KPU and Slovak University of Technology in Bratislava.

2- KPU and University of Brighton in the United Kingdom.

3- KPU and (German-Kazak and Al-Arabiya National Universities) in Kazakhstan.

4- KPU and Aditya University in India

5- KPU and UNESCO

6- KPU and University De Ouro Preto, Brazil

7- KPU and Kyrgyz Turkish Manas University

8- KPU and Freiberg University through GIZ-AMEA (German Agency for International Cooperation- Academic Mining Education in Afghanistan).

9- KPU and National Research Institute for Rural Electrification (NRIRE), China.

One of the major success stories at the MoHE and KPU has been the creation of academic partnerships between the universities in Afghanistan and universities in the developed world. Such partnerships were supported by the World Bank through a programme which was called Strengthening Higher Education Programme (SHEP). KPU was able to establish the most successful partnership (according to officials at MoHE) with University of Brighton (UoB) in the UK. Through this partnership, KPU has trained twelve junior lecturers at Masters level and one at $\mathrm{PhD}$ level in five different disciplines namely geology and minerals, computer science \& IT, construction management, electrical engineering and Geographic Information Systems (GIS). All of them have successfully finished their program of studies and have returned to Afghanistan where they are making positive contributions.

In addition, KPU also signed around twenty MoUs with key Afghan Ministries, Civil Service Commission and local companies in the last five years. These MoUs helped staff of the mentioned ministries and companies to be educated and trained according to the need of industries and also helped students from KPU to be employed in the relevant ministries and private companies after their graduation. Furthermore, many lecturers and students from provincial universities have been trained and supervised under the close supervision of their counterpart department/faculty at KPU. For example, 78 students from the department of Geological Engineering and Exploration of Mines, Faculty of Science, Nengrahar University recently collected all the relevant material for their final year thesis projects using the library and archive facilities of their counterpart department in KPU. These students were supervised under the supervision of KPU lectures and they have successfully defended their theses in March 2019.

A major contributor with the faculty of Geology and Mines of KPU in the past five years is the German Agency for International Cooperation (GIZ) who provided the financial support for both 
Freiberg University and KPU to work together to update their curricula and syllabus. It is worth mentioning that due to some constraints and administrative procedures, the updated curricula are yet to be implemented. GIZ also helped to provide relatively comprehensive lab facilities and equipment in the past one and a half years for the faculty of Geology and Mines though again due to some security challenges and constraints, summarized below, we are still waiting for the installation and inauguration of this laboratory.

Moreover, some other MoUs helped KPU to equip the laboratory of other engineering faculties. For example the KPU and Slovak University of Technology MoU resulted in the equipping and modernised the laboratory of the faculty of Chemical Engineering in KPU. Beside these, laboratories in different disciplines, e.g. department of Organic Substances Technology, Faculty of Chemical Technology, Department of Auto Mechanic Engineering, Faculty of Electromechanical Engineering, were equipped during the year 2018-2019 with the help of World Bank projects focussing on Higher Education in Afghanistan e.g. the Higher Education Development Program (HEDP).

\section{Conclusions}

The history and recent progress of education related to geology and mining have been discussed in this paper. Despite the difficulties, some progress has been achieved but there are some major challenges to overcome, which are discussed as follows:

I. Security constraints are the major challenge, as many of mineral deposits, occurrences and showings are situated in the areas where the security is not good. In addition, all areas of field and practical work of major geological subjects such as physical geology, geological mapping etc. are located in unsecure areas; the security constraints even influence the students not to visit all sites for practical work in the capital and provinces for the last two years. Although GIZ have announced several bids for the installation of the lab facilities at KPU, they were not able to find a suitable international company to install the equipment due to the lack of proper security in the country. The respective governments of such companies are not willing to allow their staff to visit Afghanistan. Furthermore, due to the lack of security, KPU has been unable to attract international scholars to the conferences which are organised at KPU and other universities in Afghanistan. An example of such a conference is the International Hindukush Geosciences Conference (IHGC), which was founded in 2007 and takes place every two years. Although KPU was able to invite few international scholars for the first four 
IHGCs, at the last two IHGC meetings only a couple of international scholars presented their papers. The Faculty of Geology and Mines in KPU has already started to organize the $7^{\text {th }}$ IHGC to be held in September this year, and it is anticipated that some international scholars will participate. International scholars are an excellent source for knowledge exchange and experience exchange for the academics in higher education, especially for junior academics and researchers in the country.

II. Updating the curriculum which was initially developed by the Soviet academics in the late 1960s has been a major issue because many senior academics were educated and trained in Russia; therefore they have major problems and challenges in order to develop and implement the new curricula. For instance, most of the machinery which is used in mining are using valves instead of semiconductor devices and microcomputers.

III. Selected academics at KPU who were educated in Russia were heavily involved in politics during the USSR invasion in Afghanistan which has affected the quality of education provided by the KPU. Regrettably, KPU was misused as a centre of politics rather than a centre for knowledge at that time. Such colleagues at KPU are still making some resistance to changes in the curriculum.

IV. Admittedly, the quality of education provided by the KPU and other Afghan universities is not of the highest standard because of the following reasons:

a) The sudden increase in the number of students entering the higher education system in the country.

b) Many of the junior academics and lecturers, particularly lecturers in provincial universities, graduated from the national universities with bachelor degrees and do not have higher qualifications.

c) The shortage and lack of suitable learning resources such as frequent electricity cuts and limited access to the internet, and to libraries and laboratories, are another major issue to be addressed.

d) When the newly equipped laboratory is inaugurated, it will benefit a few junior lecturers who have recently finished their studies abroad, whereas many of the senior and newly employed lecturers will not be qualified to use these facilities for their teaching and research.

e) The lack of proper investment in higher education: the budget of the MoHE supporting all public universities is 200 Million US Dollars. The budget of higher education has been much smaller in the previous years, i.e. between 100 to 150 Million US Dollars. 


\section{Recommendations}

To overcome the above challenges and to seek possible solutions for the existing problems as discussed earlier in this paper, the following suggestions are made:

a) Although many international universities have provided scholarships for the Afghan university lecturers in the last fifteen years, however, there are still a large number of lecturers who do not have masters and PhDs. They need to be provided with scholarships to pursue these qualifications.

b) Provision of short-duration capacity building professional courses, seminars and training for senior and junior lecturers.

c) Technical support for the universities, particularly provincial universities, to develop their curricula and syllabi according to market requirements and aligned with the economic development of the country.

d) Signing of MoUs with international universities in order to collaborate in joint research programs, scholarships (for masters and $\mathrm{PhD}$ programmes), quality assurance of teaching, supplementation of lab equipment, and accreditation. Although a couple of universities including KPU have recently had opportunities to independently prepare and draft MoUs with selected international universities, the formal procedures for signing MoUs must be processed through the ministries of Higher Education (MoHE) and Foreign Affairs (MoFA) which drastically prolong the process.

e) Although there are a number of postgraduate programs in the country, the quality needs to be enhanced through these mutual collaborations.

f) Invitation of foreign professors and professionals for enhancing the capacity building of university lecturers, technical staff and students.

g) Universities should focus on student centred and outcome based education rather than teacher focused.

h) Improvement of quality assurance of teaching and if possible, membership of global quality assurance organizations.

\section{Acknowledgement}

The authors would like to thank Dr Norman Moles, University of Brighton for proof reading the paper and making constructive suggestions to improve this paper 


\section{References}

[1]- Peter, M.C., and AGS (2006). Afghanistan, World-Class undeveloped deposits, Significant Potential for further major discoveries, Government favourable to mineral development, New Mining law, Mining Journal, SPECIAL PUBLICATION, Mining Communications Ltd. (Online). Available at: https://www.bgs.ac.uk/downloads/start.cfm?id=3201 [Accessed: 15 July 2017].

[2]- Peters, S. G., Ludington, S. D., Orris, G.J. Sutphin, D.M., Bliss, J.D., Rytuba, J.J., and Bawiec, W. J., (2007). Preliminary Non-Fuel Mineral Resource Assessment of Afghanistan 2007. USGS/AGS Open- File Report 2007-1214, Project Product No. 157. (Online). Available at: http://pubs.usgs.gov/of/2007/1214/ [Accessed: 15 September 2018].

[3]- Peters, S.G., King, T.V.V., Mack, T.J., and Chornack, M.P., eds., and the U.S. Geological Survey Afghanistan Mineral Assessment Team, (2011). Summaries of important areas for mineral investment and production opportunities of nonfuel minerals in Afghanistan: U.S. Geological Survey Open-File Report 2011-1204, 1,810 p. plus appendixes on DVD. Available at: https://pubs.usgs.gov/of/2011/1204/ ) [Accessed: 15 September 2018].

[4]- Abdullh, S.H., and Chmyriov, V. M., (1980), Geology and Mineral Resources of Afghanistan. 2 volumes (i.e. book 1- Geology of Afghanistan, book 2- Mineral resources of Afghanistan). English version, republished in 2008 by British Geological Survey, occasional publication, No. 15. 507 and 307 pages respectively. (Online). Available at: http://www.bgs.ac.uk/downloads/browse.cfm?sec=7\&cat=83 [Accessed: 15 December 2018].

[5]- KPU, (2018). Kabul Polytechnic University, Academic, Geology and Mines, (Online). Available at: https://kpu.edu.af/en/geology-mines [Accessed: 15 December 2018].

[6]- Sidiqi, Z., (2018). Higher Education in Afghanistan: Current Situation and Future Plans. [Email]. Message to: H. Waizy. 20 November 2018.

[7]- Ministry of Higher Education report (2015), National Higher Education Strategic Plan 20152019; Ministry of Higher Education (MoHE), Kabul. 